\title{
The -A162G polymorphism of the PONI gene and the risk of sporadic amyotrophic lateral sclerosis
}

\author{
Polimorfizm-A762G genu PON1 jako czynnik ryzyka rozwoju sporadycznei postaci \\ stwardnienia bocznego zanikowego
}

Dorota Zawiślak', Monika Ostrowska', Aleksandra Golenia', Monika Marona', Barbara Tomik', Paweł Wołkow², Elżbieta Gryz-Kurek', Andrzej Szzzudlik', Agnieszka Stowik'

'Department of Neurology, Jagiellonian University College of Medicine, Krakow

2Department of Pharmacology, Jagiellonian University College of Medicine, Krakow

Neurologia i Neurochirurgia Polska 2010; 44, 3: 246-250

\begin{abstract}
Background and purpose: Sporadic amyotrophic lateral sclerosis (sALS) is a devastating neurodegenerative disease, which results from complex genetic and environmental interactions. Recent studies have reported an association between several polymorphisms of the PON1 and PON2 genes and risk of sALS. The aim of the present study was to identify an association between the $-\mathrm{A} 162 \mathrm{G}$ polymorphism of the promoter region of the human PON1 gene and the risk of sALS in a Polish population.

Material and methods: We included 259 patients with a diagnosis of definite or probable sALS (76 bulbar onset, 183 limb onset) and 694 healthy controls matched for age and sex. The diagnosis of ALS was established according to El Escorial criteria. The polymorphism was studied by Single Nucleotide Polymorphism Real-Time Polymerase Chain Reaction analysis.

Results: No overall difference in the PON1-A162G genotype and allele distribution was seen between cases and controls (all $p>0.05)$. There was, however, a difference in the A allele frequency when the bulbar onset group was compared to the controls $(p=0.03)$, but this significance disappeared after the Bonferroni correction.

Conclusions: The results did not show that the $-\mathrm{A} 162 \mathrm{G}$ polymorphism of the PON1 gene is a risk factor of sALS in a Polish population; it may affect, however, bulbar onset of the disease.
\end{abstract}

Key words: amyotrophic lateral sclerosis, PON1, polymorphism.

\section{Streszczenie}

Wstęp i cel pracy: Sporadyczna postać stwardnienia bocznego zanikowego (sSLA) jest chorobą zwyrodnieniową układu nerwowego, w której etiopatogenezie kluczową rolę odgrywają interakcje między czynnikami genetycznymi i środowiskowymi. Dotychczasowe badania wskazują na istnienie zależności między polimorfizmami genów PON1 i PON2 a ryzykiem wystąpienia sSLA. Celem pracy było zbadanie, czy istnieje związek między polimorfizmem -A162G miejsca promotorowego genu PON1 a ryzykiem wystąienia sSLA w populacji polskiej.

Materiał i metody: Badanie przeprowadzono u 259 chorych, u których zgodnie z kryteriami El Escorial rozpoznano pewne lub prawdopodobne SLA (76 osób z postacią opuszkową, 183 osoby z postacią kończynową) oraz u 694 zdrowych ochotników, stanowiących grupę kontrolną dobraną pod względem wieku i płci. Polimorfizm genu PON1 był badany za pomocą reakcji łańcuchowej polimerazy DNA z analizą ilości produktu w czasie rzeczywistym.

Wyniki: Nie stwierdzono istotnych statystycznie różnic w rozkładzie genotypów i alleli genu PON1 między grupą chorych a grupą kontrolną $(p>0,05)$. Stwierdzono natomiast różnice w częstości występowania allela A między grupą chorych z postacią opuszkową w porównaniu z grupą kontrolną $(p=0,03)$, jednak po korekcie Bonferroniego wynik ten nie był już istotny statystycznie.

Wnioski: Wyniki naszego badania nie wykazały, aby polimorfizm -A162G genu PON1 był czynnikiem ryzyka sSLA w populacji polskiej, jednak sugerują, że może mieć znaczenie dla wystąpienia postaci opuszkowej tej choroby.

Słowa kluczowe: stwardnienie boczne zanikowe, $P O N 1$, polimorfizm.

Correspondence address: dr med. Dorota Zawiślak, Klinika Neurologii CM UJ, ul. Botaniczna 3, 31-503 Kraków, e-mail: zawislak13@wp.pl Received: 15.03.2009; accepted: 18.03.2010 


\section{Introduction}

Sporadic amyotrophic lateral sclerosis (sALS) is a complex motor neuron disorder whose pathogenesis is still unknown. An interaction of genetic variants and environmental exposure is proposed to be an important cause of the disease [1-4].

Paraoxonases (PONs) PON1, PON2 and PON3 are esterase enzymes that possess antioxidative properties [5]. PON1 is also able to break down organophosphate insecticides, pesticides and nerve gases [5]. The $P O N$ gene cluster is located on chromosome 7 (7q21.322.1) [5]. The PON1 gene has several common polymorphisms: some of them alter enzyme activity and some affect its expression [6]. The functional $-\mathrm{A} 162 \mathrm{G}$ (rs705381) polymorphism is located in the promoter region of the human PON1 gene [7-9]. Experimental studies on transient transfection human hepatoma cell line revealed that the $-162 \mathrm{~A}$ allele, as part of haplotypes, conferred 1.8 to 3.6-fold higher reporter expression levels of the gene than the $G$ allele [8]. In a human study the A allele was associated with increased plasma activity of the enzyme [7].

Recently, the association between different $P O N$ gene variants and sALS was shown in many different populations [3,6,10-14], with only one exception [15]. A recent meta-analysis including all published studies demonstrated that among several different polymorphisms the Q192R variant of the PON1 gene was a risk factor of sALS $(\mathrm{OR}=1.25,95 \% \mathrm{CI}: 1.07-1.45$, $p=0.004)$, although after a Bonferroni correction these results were not significant [16].

The association between the $-\mathrm{A} 162 \mathrm{G}$ polymorphism of the PON1 gene and the risk of sALS was studied in patients from Ireland, France, Quebec and Sweden and yielded negative results $[6,11]$. To date, an association between the $-\mathrm{A} 162 \mathrm{G}$ polymorphism of the $\mathrm{PON} 1$ gene and the risk of sALS has been found only in an Australian population [14].

The aim of the present study was to identify any association between the $-\mathrm{A} 162 \mathrm{G}$ polymorphism of the PON1 gene and the risk of sALS in the Polish population.

\section{Material and methods}

\section{Subjects}

We included 259 consecutive patients with sALS selected among patients of the MND outpatient clinic,
Department of Neurology, Jagiellonian University, Krakow between 2003 and 2009. All patients fulfilled the El Escorial criteria for clinically definite or probable ALS [17]. Familial ALS cases were excluded based on a positive family history of the disease.

The following information about patients was collected: age, gender, type of disease onset (bulbar or limb), and type of clinical ALS diagnosis.

The control group included 694 unrelated individuals selected from the population of Southern Poland. Control subjects had no apparent neurological disease based on the findings of a structured questionnaire and neurological examination. Controls were matched to patients with respect to age of patients at disease onset ( \pm 5 years) and gender.

Both cases and controls were of Caucasian origin and Polish descent. The local Ethical Committee approved the study protocol. All individuals gave written informed consent prior to inclusion in the study.

\section{Methods}

Genetic analyses were performed by laboratory personnel who were kept blind to sample identity. Leukocyte DNA was extracted using a commercially available kit (Boehringer Mannheim, Germany).

Genotyping was performed on an ABI PRISM ${ }^{\oplus}$ 7900HT Fast Real-Time PCR System (Applied Biosystems) using TaqMan Universal PCR Master Mix (Applied Biosystems). Amplifications were carried out using a Standard Curve (AQ) plate document to generate real-time PCR data and fluorescence was read using an Allelic Discrimination (AD) plate document. The thermal cycling protocol was: $95^{\circ} \mathrm{C}$ for $10 \mathrm{~min}$, followed by 40 cycles of $95^{\circ} \mathrm{C}$ for $15 \mathrm{~s}$ and $60^{\circ} \mathrm{C}$ for $1 \mathrm{~min}$. For each sample in the $\mathrm{AD}$ assay, a unique pair of TaqMan ${ }^{\circledR}$ MGB probes was used. One fluorescent dye detector (VIC) was a perfect match to the wild type allele and the other (FAM) to the mutant allele. SDS software (Applied Biosystems) was used to plot and automatically call genotypes based on a two parameter plot using fluorescence intensities of FAM and VIC.

Assays were ordered from Applied Biosystems as Pre-Designed/Validated Assays for PON1 (paraoxonase 1), rs705381.

\section{Statistical analysis}

Wilcoxon test was used to check the potential difference in age at disease onset, and a $\chi^{2}$ test was used to 
check the potential difference in gender distribution between the studied groups. Allele frequencies were calculated by allele counting. Deviations of the observed genotypes were identified by $\chi^{2}$ test from Hardy-Weinberg equilibrium. Association of the $-\mathrm{A} 162 \mathrm{G}$ PON1 polymorphism with sALS was studied with $\chi^{2}$ test at the level of genotypes and alleles; when the number of subjects in each group was lower than five, the Fisher exact test was used. Genetic association tests were performed in PLINK, including subsidiary analysis of dominant, recessive, genotypic, and Cochran-Armitage trend tests. Results were adjusted for multiple testing using the Bonferroni correction. After the correction a value of $p<0.012$ was considered significant. Calculations were performed using the statistical package SAS v.9.1 and PLINK v.1.06.

\section{Results}

Patients and controls presented with similar age and gender distribution (ALS group: 52.12\% males, mean age: $56.2 \pm 12.7$ years, control group: $54.47 \%$ males, mean age: $55.6 \pm 17.2$ years). Thirty percent of cases (76 patients) presented with bulbar onset.

Genotype frequencies were in Hardy-Weinberg equilibrium for the entire group as well as for patients and controls separately $(p>0.05)$.

Genotype and allele frequencies did not differ between patients and controls (Table 1).

There was no difference in the genotype and allele distribution when patients with limb onset were com- pared with the controls (Table 2). The frequency of the A allele was significantly lower in patients with bulbar onset when compared with the controls $(p=0.03)$. This significance, however, disappeared after the Bonferroni correction (Table 3).

\section{Discussion}

The present study did not show any difference in the PON1 -A162G genotype and allele distribution between patients with sALS and controls; however, patients with bulbar onset of the disease, as opposed to patients with limb onset, presented with lower frequency of the A allele as compared with the controls. Because we performed multiple comparisons, we used a Bonferroni correction to avoid a type 1 error. This resulted in decreasing the expected $p$-value to less than 0.012 . Our results, after the Bonferroni correction, were no longer significant.

Although finally we were not able to show a significant difference in the genotype and allele distribution between the bulbar onset sALS and the controls, we cannot exclude that such a difference exists. Including more patients and controls or performing a meta-analysis on existing data may answer this question. The two types of ALS distinguished at disease onset are thought to present with similar pathophysiology; however, several data highlight some differences in the clinical picture and risk factor profile [18]. Bulbar onset is more common in women and in older patients and is characterized by a shorter survival time [2,18]. Recently Chiò et al. [19] showed that a longer lasting career of a professional soc-

Table 1. Distribution of genotypes and alleles of the PONI gene -A162G polymorphism in sALS patients as compared to controls

\begin{tabular}{|c|c|c|c|c|}
\hline & $\begin{array}{c}\text { sALS } \\
(n=259)\end{array}$ & $\begin{array}{l}\text { Control group } \\
(n=694)\end{array}$ & $p$-value & OR $(95 \% \mathrm{Cl})$ \\
\hline \multicolumn{5}{|c|}{ Genotypes } \\
\hline GG & $143(55.2 \%)$ & $394(56.8 \%)$ & \multirow{3}{*}{$\begin{array}{l}0.67 * \\
0.95 * * \\
0.74 * * *\end{array}$} & \multirow{3}{*}{$\begin{array}{l}0.94(0.70-1.25)^{*} \\
0.98(0.53-1.08)^{* *}\end{array}$} \\
\hline GA & $101(39.0 \%)$ & $259(37.3 \%)$ & & \\
\hline $\mathrm{AA}$ & $15(5.8 \%)$ & $41(5.9 \%)$ & & \\
\hline \multicolumn{5}{|c|}{ Alleles } \\
\hline G & $387(74.7 \%)$ & $1047(75.4 \%)$ & \multirow[t]{2}{*}{$0.75 \ddagger$} & \multirow[t]{2}{*}{$0.96(0.76-1.21)^{\ddagger}$} \\
\hline $\mathrm{A}$ & $131(25.3 \%)$ & $341(24.6 \%)$ & & \\
\hline
\end{tabular}

* Statistical calculation based on the comparison of $A A+G A$ vs. GG genotypes $\left(\chi^{2}\right.$ test).

** Statistical calculation based on the comparison of $G G+G A$ vs. AA genotypes ( $\chi^{2}$ test).

**** The Cochran-Armitage test for trend.

$\$$ Statistical calculation based on the comparison of $G$ vs. A allele $\left(\chi^{2}\right.$ test).

sALS - sporadic amyotrophic lateral sclerosis, OR - odds ratio, CI - confidence interval 
Table 2. Distribution of genotypes of the PONI gene -A162G polymorphism in limb onset SALS patients as compared to controls

\begin{tabular}{|c|c|c|c|c|}
\hline & $\begin{array}{l}\text { sALS - limb onset } \\
(n=183)\end{array}$ & $\begin{array}{l}\text { Control group } \\
(n=694)\end{array}$ & $p$-value & OR $(95 \% \mathrm{CI})$ \\
\hline \multicolumn{5}{|c|}{ Genotypes } \\
\hline GG & $94(51.4 \%)$ & $394(56.8 \%)$ & \multirow{3}{*}{$\begin{array}{l}0.19^{*} \\
0.26^{* *} \\
0.13^{* * *}\end{array}$} & \multirow{3}{*}{$\begin{array}{l}0.81(0.59-1.12)^{*} \\
0.75(0.40-1.41)^{* *}\end{array}$} \\
\hline GA & $74(40.4 \%)$ & $259(37.3 \%)$ & & \\
\hline $\mathrm{AA}$ & $15(8.2 \%)$ & $41(5.9 \%)$ & & \\
\hline \multicolumn{5}{|c|}{ Alleles } \\
\hline G & $262(71.6 \%)$ & $1047(75.4 \%)$ & \multirow[t]{2}{*}{$0.13^{\ddagger}$} & \multirow{2}{*}{$0.82(0.63-1.06)^{\ddagger}$} \\
\hline A & $104(28.4 \%)$ & $341(24.6 \%)$ & & \\
\hline
\end{tabular}

* Statistical calculation based on the comparison of $A A+G A$ vs. GG genotypes $\left(\chi^{2}\right.$ test).

** Statistical calculation based on the comparison of $G G+G A$ vs. AA genotypes ( $\chi^{2}$ test).

**** The Cochran-Armitage test for trend.

Statistical calculation based on the comparison of $G$ vs. A allele $\left(\chi^{2}\right.$ test).

sALS - sporadic amyotrophic lateral sclerosis, OR - odds ratio, CI - confidence interval

Table 3. Distribution of genotypes of the PONI gene -A162G polymorphism in bulbar onset sALS patients as compared to controls

\begin{tabular}{|c|c|c|c|c|}
\hline & $\begin{array}{c}\text { sALS - bulbar onset } \\
(n=76)\end{array}$ & $\begin{array}{l}\text { Control group } \\
(n=694)\end{array}$ & p-value & OR (95\% Cl) \\
\hline \multicolumn{5}{|c|}{ Genotypes } \\
\hline GG & $49(64.5 \%)$ & $394(56.8 \%)$ & \multirow{3}{*}{$\begin{array}{l}0.22 * \\
0.03 * * \\
0.06 * * *\end{array}$} & \multirow{3}{*}{$\begin{array}{l}1.38(0.84-2.26)^{*} \\
\text { unavailable** }\end{array}$} \\
\hline GA & $27(35.5 \%)$ & $259(37.3 \%)$ & & \\
\hline $\mathrm{AA}$ & $0(0.0 \%)$ & $41(5.9 \%)$ & & \\
\hline \multicolumn{5}{|c|}{ Alleles } \\
\hline G & $125(82.2 \%)$ & $1047(75.4 \%)$ & \multirow{2}{*}{$0.07 \ddagger$} & \multirow{2}{*}{$1.51(0.98-2.33) \ddagger$} \\
\hline A & $27(17.8 \%)$ & $341(24.6 \%)$ & & \\
\hline
\end{tabular}

*Statistical calculation based on the comparison of $A A+G A$ vs. GG genotypes $\left(\chi^{2}\right.$ test $)$.

**Statistical calculation based on the comparison of $G G+G A$ vs. AA genotypes (Fisher exact test).

****The Cochran-Armitage test for trend.

Statistical calculation based on the comparison of $G$ vs. A allele ( $\chi^{2}$ test).

sALS - sporadic amyotrophic lateral sclerosis, $O R$ - odds ratio, $C I$ - confidence interval

cer player resulted in higher risk of bulbar onset sALS. Differences in genetic risk factor profile were also noted $[20,21]$. Al Chalabi et al. [21] showed a significantly higher proportion of bulbar onset ALS in carriers of at least one epsilon4 allele of the APOE gene compared to limb onset ALS and to the controls. Also a recently published genome-wide association study (GWAS) in sALS showed different genetic profile in the two types of sALS [22]. The bulbar onset sALS as compared with the controls was characterized by different distribution of some genetic variants in the following genes: $A M P H$, BU173572, PARP8, PCSK5 [22].
The $-\mathrm{A} 162 \mathrm{G}$ polymorphism of the PON1 gene seems to be a good candidate for a genetic risk factor of ALS. This polymorphism is located within a potential binding site of the transcription factor NF-I (nuclear factor I), which may implicate a transcriptional process of the PON1 gene [8]. The studies of Brophy et al. $[7,8]$ revealed that the $-162 \mathrm{~A}$ phenotype is related to increased activity of $P O N 1$, which means that this phenotype has the greatest hydrolytic activity against organophosphate chemicals and is more effective in protecting LDL against oxidation. There are some indications that increased exposure to organophosphate chem- 
icals and/or increased lipid oxidation may increase the risk of sALS $[4,10]$. An association between the $-\mathrm{A} 162 \mathrm{G}$ polymorphism and the risk of sALS was previously demonstrated by Morahan et al. [14]. They indicated that the A allele is a protective factor against this disease. Our results are in line with these data, suggesting that the A allele may protect against bulbar onset ALS. It is important to note that a study on French, Canadian and Swedish patients did not show any difference in the PON1-A162G genotype and allele distribution between patients with sALS and controls [11]. Moreover, no correlation was found between the studied genetic variant and different types of sALS [11].

The possible association with the $-\mathrm{A} 162 \mathrm{G}$ polymorphism of the PON1 gene was also investigated in another neurodegenerative disease, i.e. Alzheimer disease. Erlich et al. [9] found an association between the -A162G polymorphism of the PON1 gene and Alzheimer disease. However, in contrast to our results, the A allele had a deleterious effect on disease risk, both independently and as part of several haplotypes. This result was not expected by the authors. Based on their results, the authors speculated that Alzheimer disease may be associated with reduced, not elevated, as expected from experimental data, levels of serum paraoxonase.

\section{Conclusion}

The results did not show that the $-\mathrm{A} 162 \mathrm{G}$ polymorphism of the PON1 gene is risk factor of sALS. However, it may affect bulbar onset of the disease.

\section{Acknowledgments}

This research was supported by grant N402 092 $32 / 3216$

\section{Disclosure}

Authors report no conflict of interest.

\section{References}

1. Rowland L.P., Shneider N.A. Amyotrophic lateral sclerosis. N Engl J Med 2001; 344: 1688-1700.

2. Strong M.J. The basic aspects of therapeutics in amyotrophic lateral sclerosis. Pharmacol Ther 2003; 98: 379-414.

3. Saeed M., Siddique N., Hung W.Y., et al. Paraoxonase cluster polymorphisms are associated with sporadic ALS. Neurology 2006; 67: 771-776.
4. Haley R.W. Excess incidence of ALS in young Gulf War veterans. Neurology 2003; 61: 750-756.

5. Li H.L., Liu D.P., Liang C.C. Paraoxonase gene polymorphisms, oxidative stress, and diseases. J Mol Med 2003; 81: 766-779.

6. Cronin S., Greenway M.J., Prehn J.H., et al. Paraoxonase promoter and intronic variants modify risk of sporadic amyotrophic lateral sclerosis. J Neurol Neurosurg Psychiatry 2007; 78: 984-986.

7. Brophy V.H., Jampsa R.L., Clendenning J.B., et al. Effects of 5 ' regulatory-region polymorphisms on paraoxonase-gene (PON1) expression. Am J Hum Genet 2001; 68: 1428-1436.

8. Brophy V.H., Hastings M.D., Clendenning J.B., et al. Polymorphisms in the human paraoxonase (PON1) promoter. Pharmacogenetics 2001; 11: 77-84.

9. Erlich P.M., Lunetta K.L., Cupples L.A., et al. Polymorphisms in the PON gene cluster are associated with Alzheimer disease. Hum Mol Genet 2006; 15: 77-85.

10. Slowik A., Tomik B., Wolkow P.P., et al. Paraoxonase gene polymorphisms and sporadic ALS. Neurology 2006; 67: 766-770.

11. Valdmanis P.N., Kabashi E., Dyck A., et al. Association of paraoxonase gene cluster polymorphisms with ALS in France, Quebec, and Sweden. Neurology 2008; 71: 514-520.

12. Landers J.E., Shi L., Cho T.J., et al. A common haplotype within the PON1 promoter region is associated with sporadic ALS. Amyotroph Lateral Scler 2008; 9: 306-314.

13. Wills A.M., Landers J.E., Zhang H., et al. Paraoxonase 1 (PON1) organophosphate hydrolysis is not reduced in ALS. Neurology 2008; 70: 929-934.

14. Morahan J.M., Yu B., Trent R.J., et al. A gene-environment study of the paraoxonase 1 gene and pesticides in amyotrophic lateral sclerosis. Neurotoxicology 2007; 28: 532-540.

15. Kasperaviciute D., Weale M.E., Shianna K.V., et al. Large-scale pathways-based association study in amyotrophic lateral sclerosis. Brain 2007; 130: 2292-2301.

16. Wills A.M., Cronin S., Slowik A., et al. A large-scale international meta-analysis of paraoxonase gene polymorphisms in sporadic ALS. Neurology 2009; 73: 16-24.

17. Brooks B.R., Miller R.G., Swash M., et al. El Escorial revisited: Revised criteria for the diagnosis of amyotrophic lateral sclerosis. Amyotroph Lateral Scler Other Motor Neuron Disord 2000; 1: 293-299.

18. Wijesekera L.C., Leigh P.N. Amyotrophic lateral sclerosis. Orphanet J Rare Dis 2009; 4: 3.

19. Chiò A., Benzi G., Dossena M., et al. Severely increased risk of amyotrophic lateral sclerosis among Italian professional football players. Brain 2005; 128: 472-476.

20. Moulard B., Sefiani A., Laamri A., et al. Apolipoprotein E genotyping in sporadic amyotrophic lateral sclerosis: evidence for a major influence on the clinical presentation and prognosis. J Neurol Sci 1996; 139 (Suppl): 34-37.

21. al-Chalabi A., Enayat Z.E., Bakker M.C., et al. Association of apolipoprotein $\mathrm{E}$ epsilon 4 allele with bulbar-onset motor neuron disease. Lancet 1996; 347: 159-160.

22. Dunckley T., Huentelman M.J., Craig D.W., et al. Wholegenome analysis of sporadic amyotrophic lateral sclerosis. $N$ Engl J Med 2007; 357: 775-788. 